\title{
Growth Suppression Of Some Common Post Harvest Rot Fungi By Culture Filtrates Of A Soil Isolate Of Trichoderma Viride.
}

\author{
T.P. Terna ${ }^{1}$, A.C. Odebode ${ }^{2}$ and A.A. Bem ${ }^{1}$ \\ ${ }^{I}$ Department of Biological Sciences, Federal University, Dutsin-Ma, PMB 5001, Dutsin-Ma, Katsina State, \\ Nigeria. \\ ${ }^{2}$ Department of Botany and Microbiology, University of Ibadan, P.O. Box 21422, Ibadan, Oyo State, Nigeria.
}

\begin{abstract}
The antagonistic potential of culture filtrates of a soil isolate of T. viride was evaluated invitro, against three common post-harvest rot pathogens; A. niger, A. flavus, and F. oxysporum. Assay of three extracellular enzymes; chitinase, protease and cellulase, in respective enzyme-induced culture filtrates revealed the presence of enzyme activity. When $10 \%(\mathrm{v} / \mathrm{v})$ concentration of the various lytic enzyme-induced culture filtrates were screened for antagonistic activity against three post-harvest rot fungi on Potato Dextrose Agar (PDA) medium, it was observed that, while the synergistic combination of all three enzyme-induced culture filtrates (chitinase, protease and cellulase) of T. viride gave the highest radial growth inhibitions, $77.69 \%$ and 67.89\% of A. niger and A. flavus respectively, chitinase induced culture filtrates of T. viride gave the highest radial growth inhibition, $46.95 \%$ of $F$. oxysporum. The T. viride strain used in the study showed potent antagonistic activity and could be considered a potential biocontrol agent against A. niger, A. flavus, and F. oxysporum.
\end{abstract}

Key words: Antagonistic activity, culture filtrates, lytic enzymes, post-harvest rot fungi, soil isolate

\section{Introduction.}

Phyto pathogenic microorganisms, particularly fungi, are a major threat to food production and ecosystem stability worldwide [1]. Today, about $30 \%$ of all plant species have been destroyed by plant pathogens [2]. This implies therefore that, in order to maintain sustainable food production, control of pre and post harvest plant disease pathogens is imperative. In addition to good agronomic practices, the use of chemical pesticides has over the years contributed to significant plant disease control and enhancement of crop yield. However, the resultant problems ranging from the development of pathogen resistance, the growing cost of pesticides, to their unpleasant environmental effect, have called for the development and use of better approaches to plant disease management [3 - 6]. Among these approaches are those referred to as biological controls [6], which involve the inhibition of disease producing activities of a pathogen by one or more organisms $[7,6]$

Trichoderma species have become the research focus of several researchers seeking to develop potent biocontrol agents of fungal origin $[8,9]$. The success of several members of the genus Trichoderma in biocontrol of plant pathogens has been attributed chiefly to the activation of a variety of direct (active) and indirect (passive) mechanisms [1,9]. Direct mechanisms of biological control of plant pathogens by Trichoderma species involve mycoparasitism, aided by the production of cell wall degrading enzymes, while indirect or passive mechanisms include competition for nutrients and space, modifying the pathogens environmental conditions (e.g. pH), antibiosis and promotion of plant growth and defence mechanisms [1,8, 1017]. However, due to inter-specific and inter-strain variations in the genus Trichoderma with respect to biocontrol activity, only the isolate most active in the antagonism of a particular pathogen can be considered as biocontrol agent against the pathogen [18]. This experiment is therefore aimed at investigating the relative effectiveness of a $T$. viride strain in the biological control of three common post harvest rot fungi, namely; $A$. niger, A. flavusand $F$. oxysporum, as a preliminary effort towards selecting the most effective biocontrol agent against the named pathogens in the study area.

\subsection{Fungal isolates}

\section{Materials and Methods}

Post harvest rot fungi, namely A. niger and A. flavus used in this study were kindly donated by Mr. Tivkaa Amande of the Department of Botany and Microbiology, University of Ibadan, while the F. oxysporum isolate was obtained from a mixture of soil and decayed debris collected from Bodija market refuse dump, Ibadan, Nigeria, using the soil dilution plate method [19]. T. viride was isolated from soil samples [19] collected from the demonstration farm of the Institute of Agricultural Research and Training (IAR\&T), Ibadan, Nigeria, and identified in the Plant Pathology Laboratory of the Department of Botany and Microbiology, University of 
Ibadan, using the identification keys of Rifai [20] and Domsch et al. [21]. Isolates were thereafter preserved on Potato Dextrose Agar (PDA) slants in McCartney bottles and maintained temporarily at $28 \pm 2^{\circ} \mathrm{C}$.

\subsection{Growth conditions for metabolite production by the antagonist}

Three different growth media were used to induce the production of the lytic enzymes chitinases, proteases and cellulases respectively by the antagonist in addition to other antimicrobial metabolites. For protease induction, the medium of De Marco and Felix [22] was used with slight modifications as follows: Bactopeptone (0.1\%), Urea (0.03\%), $\mathrm{KH}_{2} \mathrm{PO}_{4}(0.2 \%),\left(\mathrm{NH}_{4}\right){ }_{2} \mathrm{SO}_{4}(0.14 \%), \mathrm{MgSO}_{4} \cdot 7 \mathrm{H}_{2} \mathrm{O}(0.03 \%), \mathrm{CaCl}_{2} \cdot 6 \mathrm{H}_{2} \mathrm{O}$ $(0.03 \%)$, Casein $(0.5 \%)$, Glucose $(0.02 \%), 1 \mathrm{ml}$ of $0.01 \%$ trace elements solution $\left(\mathrm{Fe}^{2+}, \mathrm{Mn}^{2+}, \mathrm{Zn}^{2+}\right.$, and $\left.\mathrm{CO}^{2+}\right)$, pH 5.5 (0.2M Sodium acetate buffer). For chitinase induction, a modified medium of Kucuk and Kivanc [2] was used as follows (g/l of distilled water): $\mathrm{MgSO}_{4} \cdot 7 \mathrm{H}_{2} \mathrm{O}, 0.2 ; \mathrm{KH}_{2} \mathrm{PO}_{4}, 0.9 ; \mathrm{KCl}, 0.2 ; \mathrm{NH}_{4} \mathrm{NO}_{3}, 1.0 ; \mathrm{Fe}^{2+}, 0.002$; $\mathrm{Zn}^{2+}, 0.002 ; 10 \mathrm{~g}$ of finely sieved prawn waste powder $(0.4 \mathrm{~mm}$ mesh size), $\mathrm{pH} 5.5$ (0.2M Sodium acetate buffer). Lastly, the medium of Mendels and Weber [23] was used for cellulase induction as follows ( $\mathrm{g} / \mathrm{l}$ of distilled water): Cellulose powder, $10 ; \mathrm{MgSO}_{4} \cdot 7 \mathrm{H}_{2} \mathrm{O}, 0.2 ; \mathrm{KH}_{2} \mathrm{PO}_{4}, 2.0 ;\left(\mathrm{NH}_{4}\right)_{2} \mathrm{SO}_{4}, 1.4$; Urea, $0.3 ; \mathrm{CaCl}_{2} \cdot 2 \mathrm{H}_{2} \mathrm{O}, 0.4$; peptone, 0.75 ; yeast extract, $0.25 ; \mathrm{FeSO}_{4} \cdot 7 \mathrm{H}_{2} \mathrm{O}, 0.005 ; \mathrm{MnSO}_{4} \cdot 4 \mathrm{H}_{2} \mathrm{O}, 0.0016 ; \mathrm{ZnSO}_{4} \cdot 7 \mathrm{H}_{2} \mathrm{O}, 0.0014$; $\mathrm{CoCl}_{2} \cdot 6 \mathrm{H}_{2} \mathrm{O}, 0.02, \mathrm{pH} 5.5(0.1 \mathrm{M}$ Sodium citrate buffer $)$.

\subsection{Culture of antagonist and collection of culture filtrates.}

Three $7 \mathrm{~mm}$ mycelia plugs from actively growing regions of 3-5 days old cultures of antagonist were aseptically obtained and introduced into $15 \mathrm{ml}$ volume of each sterilized fermentation media in McCartney bottles and incubated at $30^{\circ} \mathrm{C}$ for a total duration of 7 days, during which the various enzyme induced culture filtrates were collected at days 3, 5, and 7 via filtration using a double membrane Watman no.1 filter paper [24]. Centrifugation of filtrates was carried out at $8000 \mathrm{rpm}$ for $10 \mathrm{mins}$ at $10^{\circ} \mathrm{C}$ (high speed refrigerated centrifuge), after which carefully decanted supernatants were used for enzyme assays and probe of antagonistic activity.

\subsection{Carboxymethyl Cellulase Assay}

For assay of Carboxymethyl cellulase (CMC) activity, the method of Ghose [25] was used. $0.9 \mathrm{ml}$ of $1 \%(\mathrm{w} / \mathrm{v}) \mathrm{CMC}$ (prepared in 0.1M Na-citrate buffer, $\mathrm{pH} 5.3$ ) were mixed with $0.1 \mathrm{ml}$ of culture filtrate (cellulase induced) and incubated at $30^{\circ} \mathrm{C}$ for 15 minutes. The reaction was stopped by the addition of $1.5 \mathrm{ml}$ of 3,5dinitrosalicylic acid (DNSA) reagent and the content boiled for 5minutes. The colour developed was read at $540 \mathrm{~nm}$, and the amount of reducing sugar liberated was quantified using glucose as standard.

\subsection{Protease assay}

This assay was carried out using the method of method of Kunitz [26] with slight modifications. 1\% $(\mathrm{w} / \mathrm{v})$ casein solution was prepared in $0.1 \mathrm{M}$ Citrate phosphate buffer $(\mathrm{pH} 7)$ and heat denatured at $100^{\circ} \mathrm{C}$ for 15 minutes in water bath and allowed to cool. The reaction mixture consisting of $1 \mathrm{ml}$ of substrate thoroughly mixed with $0.5 \mathrm{ml}$ of culture filtrate (protease induced), was incubated at $35^{\circ} \mathrm{C}$ for 1 hour, after which the reaction was terminated by addition of $3 \mathrm{ml}$ of cold $\left(2^{\circ} \mathrm{C}\right) 10 \%$ Trichloro Acetic Acid (TCA). Tubes were allowed to stand for another 1 hour to allow precipitation of undigested protein. Control tubes containing $0.5 \mathrm{ml}$ of culture filtrate were incubated for 1 hour at $35^{\circ} \mathrm{C}$ before adding $3 \mathrm{ml}$ of cold $\left(2^{\circ} \mathrm{C}\right) 10 \%$ TCA and $1 \mathrm{ml}$ of $1 \%$ casein. The reaction mixtures were then centrifuged at $10000 \mathrm{rpm}$ at $4^{\circ} \mathrm{C}$ for 5 minutes. Absorbance readings were taken at $660 \mathrm{~nm}$ against a blank containing the control. Amount of reducing sugar liberated was quantified using casein as standard.

\subsection{Chitinase assay}

Assay of chitinase activity was carried out using a modification of the calorimetric method described by Molano et al. [27]. The assay mixture contained $1 \mathrm{ml}$ of $0.5 \%$ pure chitin (Sigma, suspended in $0.2 \mathrm{M}$ acetate buffer $\mathrm{pH}$ 5.2) and $1 \mathrm{ml}$ of culture filtrate (chitinase induced). The reaction mixture was incubated for 10 minutes at $50^{\circ} \mathrm{C}[28]$ and stopped by the addition of $1 \mathrm{ml}$ of DNSA in a total volume of $3 \mathrm{ml}$. Absorbance readings taken spectrophotometrically at $540 \mathrm{~nm}$ were converted to concentration using the molar extinction coefficient of $\mathrm{p}$ Nitrophenyl (pNP), $1.8 \times 10^{4} \mathrm{M}^{-1} \mathrm{Cm}^{-1}[29]$.

\subsection{Determination of total protein content of culture filtrates.}

For the estimation of total protein content of culture filtrates, the protocol of Lowry et al. [30] was employed. 


\subsection{Determination of antagonistic activity of culture filtrates of antagonist ( $T$. viride).}

The method described by El-Katatny et al. [31] was adopted. Agar plates of quarter strength PDA were prepared with $10 \%$ concentrations of various enzyme induced culture filtrates of the antagonist and allowed to solidify, after which plates were inoculated separately at the center with $5 \mathrm{~mm}$ diameter mycelia disc of rot fungi (A. niger, A. flavus and F. oxysporum) obtained from actively growing regions of 2-7 days old cultures. Treatments were applied in duplicates and plates incubated at $30^{\circ} \mathrm{C}$ for 5 days. Radial growth of the pathogens was taken as the average of colony diameter measured at right angles, and percentage pathogen growth inhibition calculated with respect to radial growth of pathogen on control plates (without culture filtrates) as in Eq. (1):

$$
\mathrm{PRG}=\frac{\mathrm{Pc}-\mathrm{P}}{\mathrm{Pc}} \times 100
$$

Where, $\mathrm{PRG}=$ Percentage radial growth inhibition, $\mathrm{Pc}=$ radial growth of pathogen in control plate and $\mathrm{P}=$ Radial growth of the pathogen in the presence of culture filtrates of $\mathrm{T}$. viride.

\subsection{Lytic enzyme production.}

\section{Results}

Assay of lytic enzyme activity (Fig. 1) revealed maximal enzyme production after 7days of incubation for all enzymes assayed. Protease had the highest concentration $(1.35 \mathrm{mg} / \mathrm{ml})$, followed by chitinase $(1.14 \mathrm{mg} / \mathrm{ml})$, and lastly cellulase $(1.11 \mathrm{mg} / \mathrm{ml})$.

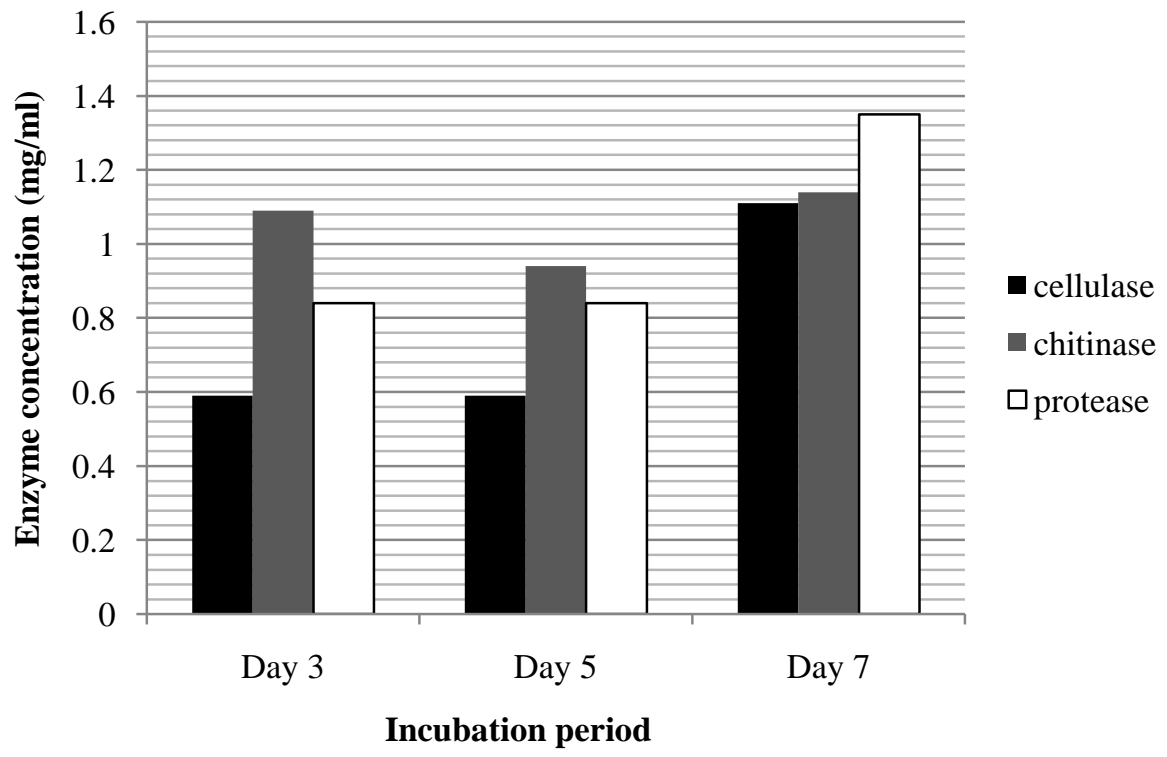

Figure 1. Lytic enzyme production by $T$. viride.

\subsection{Growth inhibitory effect of cellulase induced culture filtrates of T.viride on rot fungi.}

When $10 \%(\mathrm{v} / \mathrm{v})$ concentration of cellulase induced culture filtrates were introduced into solidified PDA (Potato Dextrose Agar) on which the rot fungi were grown (Fig. 2), it was observed that radial growth of A. niger was inhibited the most $(45.04 \%)$ after 5 days of incubation at $30^{\circ} \mathrm{C}$, followed by $F$. oxysporum $(35.48 \%)$ after 3 days of incubation. 


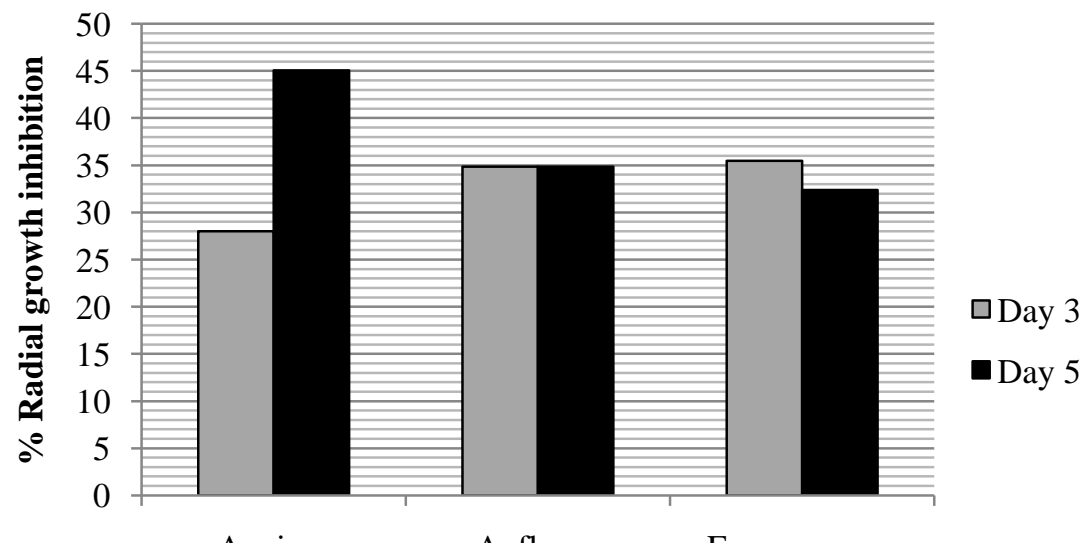
A. niger
A. flavus
F. oxysporum

Pathogen

Figure 2. Growth inhibitory effect of cellulase induced culture filtrates of $T$. viride on rot fungi

\subsection{Growth inhibitory effect of chitinase induced culture filtrates of $T$. viride on rot fungi.}

Inoculation of $10 \%(\mathrm{v} / \mathrm{v})$ concentration of chitinase induced culture filtrates (Fig. 3) in solidified PDA on which the rot fungi were cultured resulted to $66.94 \%, 46.95 \%$ and $42.66 \%$ radial growth inhibitions of A. niger, F. oxysporum and A. flavus respectively after 5 days of incubation at $30^{\circ} \mathrm{C}$. Radial growth inhibitions increased steadily and peaked on the $5^{\text {th }}$ day of incubation.

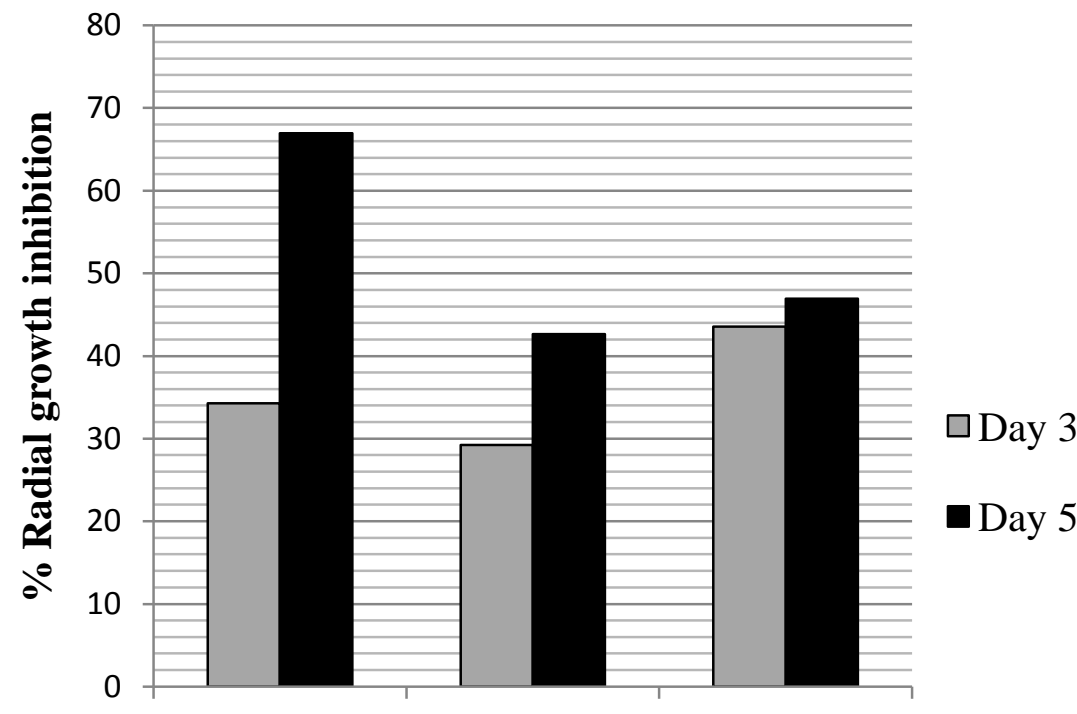
A. niger
A. flavus
F. oxysporum
Pathogen

Figure 3. Growth inhibitory effect of chitinase induced culture filtrates of $T$. viride on rot fungi

\subsection{Growth inhibitory effect of Protease induced culture filtrates of $\boldsymbol{T}$. viride on rot fungi.}

Application of $10 \%(\mathrm{v} / \mathrm{v})$ concentration of protease induced culture filtrates of the antagonist (Fig. 4) in solidified PDA on which the rot fungi were grown resulted to $72.73 \%, 43.58 \%$ and $30.05 \%$ radial growth inhibitions of A. niger, A. flavus and F. oxysporum respectively after 5 days of incubation at $30^{\circ} \mathrm{C}$. Growth inhibition of test fungi by protease induced culture filtrates of the antagonist increased steadily from the $3^{\text {rd }}$ day and peaked on the $5^{\text {th }}$ day of incubation. 


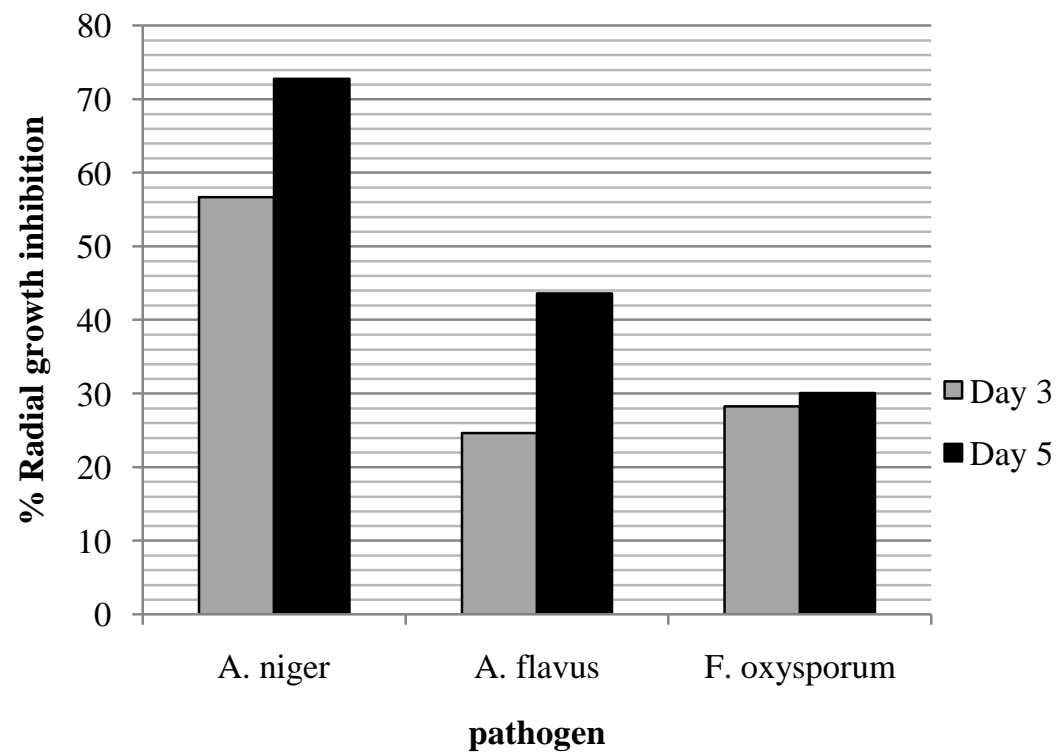

Fig. 4. Growth inhibitory effect of protease induced culture filtrates of $T$. viride on rot fungi

3.5 Synergistic effect of lytic enzyme -induced culture filtrates (cellulase, chitinase and protease, ratio 1:1:1) of $T$. viride on pathogens' growth.

When $10 \%(\mathrm{v} / \mathrm{v})$ concentrations of all three (cellulase, chitinase and protease) lytic enzyme induced culture filtrates of $T$. viride (the antagonist) were combined (ratio 1:1:1) in solidified PDA on which the test fungi were grown and incubated at $30^{\circ} \mathrm{C}$ (Fig. 5) for 5 days, radial growth of A. niger was inhibited the most (77.69\%) followed by A. flavus (67.89\%) and lastly F. oxysporum (42.72\%), after 5 days of incubation. In all cases of synergistic application, growth inhibition of test fungi by lytic enzyme induced culture filtrates of the antagonist increased steadily from the $3^{\text {rd }}$ day and peaked on the $5^{\text {th }}$ day of incubation.

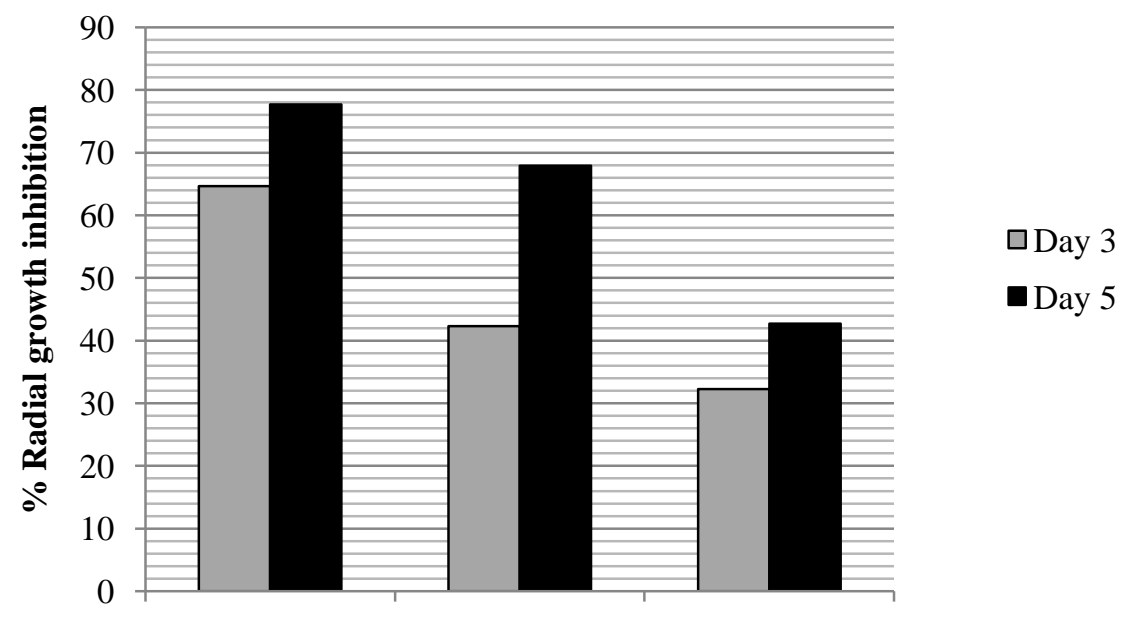
A. niger
A. flavus
F. oxysporum

Pathogen

Figure 5. Synergistic effect of lytic enzyme -induced culture filtrates (cellulase, chitinase and protease, ratio 1:1:1) of $T$. viride on pathogens' growth. 


\section{Discussion}

The ability of the $T$. virde strain used in the study to produce lytic enzymes increased with incubation time. In a similar study, Ul-haque [32] reported highest celluase production by $T$. viride after 72 hours of incubation. El-katatny et al. [31] reported that while the production of chitinase by $T$. harzianum using a medium containing chitin reached a maximum after 7 days of growth and decreased afterwards, synthesis of $\beta$ 1,3-glucanase peaked at day 4. According to Harman et al. [16], Trichoderma species are prolific producers of extracellular proteins, and are best known for their ability to produce enzymes that degrade cellulase and chitin. The behavior of strains with respect to peak of induced production of extracellular enzymes, vary and depends on strain, carbon source and cultural conditions [33].

In the study, it was also observed that the radial growth of pathogens was greatly inhibited by $10 \%$ $(\mathrm{v} / \mathrm{v})$ concentration of various enzyme-induced culture filtrates of the antagonist (T. viride). This suggests the presence and action of non-volatile antibiotics in the filtrates as rightly reported by Odebode [34], Sivan et al. [35], Watts et al. [36], and Siameto et al. [37] amongst others. In a similar work, Yaqub and Shahzad [38] reported that $T$. viride isolated from partially decomposed fruits and vegetable wastes showed inhibitory effects on some common post-harvest pathogens of fruits and vegetables, namely; A. niger, A. flavus, Fusarium sp., A. fumigatus and Penicillium sp. Invitro. From their findings, maximum growth inhibition of A. niger, A. fumigatus and A. flavus, were found with the use of 50\% culture filtrate in medium. Another work by Ubalua and Oti [39] on the antagonistic properties of T. viride on post-harvest cassava root rot pathogens confirmed that while $100 \%$ concentration of culture filtrates gave absolute inhibition of Botryodiplodia theobromae, A. niger, F. solani and Rhizopus sps., $10 \%$ gave $48.4 \%, 51.3 \%, 39.6 \%$ and $65.2 \%$ inhibition respectively. Similar observations have also been reported by Calistru et al. [40], Adebesin et al. [41] and El-Katatny et al. [31]

\section{Conclusion and Recommendations.}

The T. viride strain used in the study exhibited potent antagonistic activity as evidenced by the relatively high percentages of radial growth inhibitions of the test fungi. The antagonist could therefore be adopted as a potential biocontrol agent in the control of A. niger, A. flavus and $F$. oxysporum related postharvest rot diseases. Further study could include dual culture tests for antagonism, in vivo experiments and exploring the possibility of the biocontrol of other plant disease pathogens other than those considered in the study.

\section{References}

[1] A.M. Benitez, T. Rincón, M.C. Limón, A.C. Codon, Biocontrol mechanisms of Trichoderma strains, International Microbiology, 7, 2004, 1-260.

[2] C. Kucuk and M. Kivanc, Isolation of Trichoderma spp. and Determination of Their Antifungal, Biochemical and physiological Features, Turkish Journal of Biology, 27, 2003, 247, 248.

[3] S. Compant, B. Duffy, J. Nowak, C. Clement, Use of Plant Growth-Promoting Bacteria for Biocontrol of plant Diseases: Principles, Mechanisms of Action, and Future Prospects, Journal of Applied and Environmental Microbiology, 71, $2005,4951$.

[4] H. Behzad, T. Mousa, RM. Mohammad, D. Mahdi, Biological potential of some Iranian Trichoderma isolates in the control of soil borne plant pathogenic fungi, African Journal of Biotechnology, 7, 2008, 967-972.

[5] M. R. Hermosa, I. Grondona, E.A. Iturriaga, J.M. Diaz-Minguez, C. Casytro, E. Monte and I. Garcia-Acha, Molecular characterization and identification of biocontrol isolates of Trichoderma spp., Applied Environmental Microbiology, 66, 2000, 1890 $-1898$

[6] K.K. Pal and B.M. Gardener, Biocontrol of Plant Pathogens (Ohio: Apsnet Education Center, 2006)

[7] K.F. Baker and O. Cook, Biological control of plant pathogens (San Francisco: W.B. Freeman, 1974)

[8] M. Verma, S.K. Brar, R.D. Tyagi, R.V. Surampalli, J.R. Valero, Antagonistic Fungi, Trichoderma spp.: Panoply of Biological Control, Biochemical Engineering Journal, 37, 2007.

[9] A. Kundu, M.R. Chakraborty and N.C. Chatterjee, Biocontrol of wood Decay by Trichoderma spp. - Retrospect and prospect, Journal Experimental Sciences, 22, 2008, 373-384.

[10] Y. Henis, Interactions between Sclerotium rolfsii and Trichoderma spp., relationship between antagonism and disease control, Soil Biology and Biochemistry, 16, 1984, 391-395.

[11] G.C. Papavizas, Trichoderma and Gliocladium: Biology, Ecology and Potential for Biocontrol, Annual Review of Phytopathology, 23, 1985, 23-54.

[12] I. Chet, Innovative Approaches to Plant Disease Control (New York: Wiley Interscience, 1987).

[13] J.M. Lynch, Introduction: some consequences of microbial rhizosphere competence for plant and soil, in J.M. Lynch (Ed.), The Rhizosphere (New York: Wiley, 1990).

[14] H.D. Wells, Trichoderma as a biocontrol agent, in K.J. Mukerji, K.L. Gary, (Eds.), Biocontrol of Plant Diseases Vol.1, (Boca Raton, FL.: CRC Press, 1988)

[15] A.A. Sobowale, Biological control of Fusarium moniliforme (Shield.) on maize stems by some fungal isolates from maize phyllosphere and rhizosphere, Ph.D Thesis, University of Ibadan, Nigeria, 2002.

[16] G.E. Harman, C.R. Howell, A. Viterbo, I. Chet and M. Lorito, Trichoderma species opportunistic, avirulent plant symbionts, Nature Reviews Microbiology 2 (2004) 43-56.

[17] C.R. Howell, Mechanisms Employed by Trichoderma species in the Biological Control of Plant Diseases: The History and Evolution of Current Concepts, The American Phytopathological Society 87, 2003, 4-9.

[18] D.J. Roiger and S.N. Jeffers, Evaluation of Trichoderma spp. for the biological control of Phtophthora crown and root rot of apple seedlings, Journal of phytopathology, 81, 1991, 910-917.

[19] S.A. Waksman, Principles of Soil Microbiology (London: Bailliere Tindall \& Co., 1927). 
[20] M.A. Rifai, Revision of Genus Trichoderma, Mycological Papers, 116,1969, 1-56.

[21] K.H. Domsch, W. Gams and T. Anderson, Compendium of soil fungi (New York: Academic Press, 1980).

[22] L.J. De Marco and R.C. Felix, Characterization of a protease produced by a Trichoderma harzianum isolate which controls cocoa plant witches' broom disease, BMC Biochemistry 3, 2002, 1-7.

[23] M. Mendels and J. Weber, Production of Cellulases, Advances in Chemistry, 95, 1969, 391-414

[24] A. Imtiaj, and T.S. Lee, Antagonistic effect of three Trichoderma species on the Alternaria porri pathogen of onion blotch, World Journal of Agricultural Sciences 4, 2008, 13-17.

[25] T.K. Ghose, Measurement of Cellulase Activity, Journal of Pure \& Applied Chemistry, 59, 1987, 257-268.

[26] M. Kunitz, Crystalline soybean trypsin inhibitor II. General properties, Journal of General Physiology, 30, 1947, 291-310.

[27] J. Molano, A. Duram, and E. Cabib, Annals of Biochemistry, 8, 1977, 648

[28] E.W. Gachomo and S.O. Kotchoni, The Use of Trichoderma harzianum and T. viride as Potential Biocontrol Agents Against Peanut Microflora and Their Effectiveness in Reducing Aflatoxin Contamination of Infected Kernels, Biotechnology, 7, 2008, 439447.

[29] M. L. Bender, F. J. Kezdy, and F. C. Wedler, $\alpha$-Chymotrypsin: Enzyme concentration and kinetics, Journal of Chemistry Education, 44, 1967, 84-88.

[30] O.H. Lowry, N.J. Rosenbrough, A.L. Farr, R.J. Randall, Protein measurement with the Folin Reagent, Journal of Biochemistry, 193, 1951, 265-275

[31] M.H. El-Katatny, M. Gudelj, K.H. Robra, M.A. Elnaghy, and G.M. Gubitz, Chracterization of a chitinase and an endo- $\beta-1,3-$ glucanase from Trichoderma harzianum Rifai T24 involved in control of the phyto pathogen Sclerotium rolfsii, Applied Microbiology and Biotechnology 56, 2001, 137-43.

[32] I. Ul-Haque, Optimization of cellulase synthesis by locally isolated Trichoderma species using agricultural by-products as substrates, Ph.D Thesis, Department of Botany, University of Punjab, Lahore, Pakistan, 1992.

[33] M. Schirmbock, M. Lorito, Y. Wang, K.C. Hayes, I. Arisan-Atac, F. Scala, E.G. Harman and P.C. Kubicek, Parallel formation and synergism of hydrolytic enzymes and peptaibol antibiotics, molecular mechanisms involved in the antagonistic action of Trichoderma harzianum against phytopathogenic fungi, Applied and Environmental Microbiology, 60, 1994, 4364-4370.

[34] A.C. Odebode, Control of Post harvest pathogens of fruits by culture filtrate from antagonistic fungi, Journal of Plant Protection Research, 46, 2006, 1-4

[35] A. Sivan, Y. Elad and I. Chet, Biological control effects of a new isolate of Trichoderma harzianum on Pythium aphanidermatum, Phytopathology, 74, 1984, 498-501.

[36] R. Watts, J. Kahiya, K. Chaudhary, and P. Tauro, Isolation and Chracterization of a new antifungal metabolite of Trichoderma reesei, Journal of Biomedical and Life Sciences, 107, 1988, 81-84.

[37] E.N. Siameto, S. Okoth, N.O. Amugum, N.C. Chege, Antagonism of Trichoderma harzianum isolates on soil borne plant pathogenic fungi from Embu District, Kenya, Journal of Yeast and Fungal Research, 1, 2010, 47-54.

[38] F. Yaqub and S. Shahzad, Invitro Evaluation of microbial antagonists against Sclerotium rolfsii, Pakistani Journal of Botany, 37, 2005, 1033-1036.

[39] A.O. Ubalua and E. Oti, Antagonistic properties of Trichoderma viride on post harvest cassava root rot pathogens, African Journal of biotechnology, 6, 2007, 2447-2450.

[40] C. Calistru, M. McLean and P. Berja, In vitro studies of the potential for biological control of Aspergillus flavus and Fusarium moniliforme by Trichoderma species 1. Macroscopical and microscopical observations of fungal interations, Mycopathology 139, 1997, 115-121.

[41] A.A. Adebesin, A.C. Odebode, and A.M. Ayodele, Control of Postharvest Rots of Banana Fruits by Conidia and Culture Filtrates of Trichoderma Asperellum, Journal of Plant Protection Research, 49, 2006, 302-308 